\title{
Logistics Sustainability?: Long Term Technology Investments and Integration
}

\author{
Jack E. Tucci ${ }^{1}$, Seungjae Shin $^{2} \&$ Mike Benefield ${ }^{1}$ \\ ${ }^{1}$ College of Business, Arkansas Tech University, Russellville, Arkansas, USA \\ ${ }^{2}$ College of Business, Mississippi State University, Meridian, Mississippi, USA \\ Correspondence: Jack E. Tucci, William M. Lemley Endowed Chair, College of Business, Arkansas Tech \\ University, Rothwell Hall, Room 445, 106 West "O" Street, Russellville, Arkansas, 72801 United States of \\ America. Tel: 1-479-968-0608. E-mail: jtucci@atu.edu
}

Received: March 18, 2015 Accepted: April 10, 2015 Online Published: May 31, 2015

doi:10.5539/jms.v5n2p48 URL: http://dx.doi.org/10.5539/jms.v5n2p48

\begin{abstract}
This study examines the investment in technology over time in an effort to achieve sustainability and secondarily to support green initiatives by minimizing environmental impacts. The literature suggests integrated supply chain contractors emphasize efficiency and flexibility which leads to organizational performance improvements. This study compares productivity changes in the logistics industry measures after significant RFID investments over time. Productivity ratios collected for the fiscal years of 2000-2013 from financial statements are used to investigate technology investments effects.Since 2003, many end users (Wal-Mart specifically) mandated the implementation of RFID technology as one part of a larger system in reaching long term sustainability objectives. Historically, B2B customers and retailers have either built in-house logistic systems or have relied on either shippers services, i.e., third party logistic suppliers (3PL) or independent fourth party logistic suppliers (4PL). Logistic companies that have invested in logistical technologies aimed at sustainability strategies have improved financial ratios during the period studied. Interestingly, companies who have not fully implemented technology enhancements because of logistic service type have not seen improvements in productivity at the same level as others in the supply chain during this same period.
\end{abstract}

Keywords: rfid, productivity, sustainability, logistics, 3PL, 4PL, intermodal, e-card

\section{Introduction}

Differing parts of the logistics industry were early adopters in investing in technologies as they reached towards sustainability, efficiencies and improved profits. Further pressure is the impetus towards green initiatives (Shin and Tucci, 2015). The investment in RFID technology began in 1994 and was spurred from the bar-coding initiatives in the 1990's. Much of the recent productivity successes of the logistics industry can be attributed to the strategy of low-cost leadership and when combined with the goal of sustainability has led to clear advantages to those who have implemented and taken full advantage of what RFID technologies offers. Supply chain management has emerged in the last decade as an area of greatest opportunity to not only fine tune integrated distribution systems, but also help fulfill aspirations of being "green."To understand the importance and impact the logistics industry has on sustainability, the McKinsey Global Institute reports that a quarter of U.S. productivity growth is attributable to the retail industry from 1995 to 2000, (Freeman et al., 2011) all of whom benefitted from lower costs due to reduced costs fromthe logistics industry.

\subsection{Technology Impact}

Many scientists have postulated the driving factors behind the concerns about the closed system ecology of our planet are finite resources with ever increasing demand (O'Neill et al., 2004; Ehrlich \& Holdren, 1971; Commoner 1972). However, most are in agreement that the I-PAT model is the generally accepted standard for calculating Human Impact on our shared environment (Chertow, 2000). Responsible retailers realize that their ability to manage Human Impact (I) is limited to primarily to the " $T$ " technology variable and secondarily to the "A" affluence variable as it relates to consumption. The "P" population variable is a social issue beyond the control of privately owned logistic operator/suppliers.In spite of the critics of sustainability/green initiatives who plainly state that companies who are "greening" are in reality only "greenwashing" for PR sake. Nevertheless, 
sustainability and green initiative analysis should be made with clear analysis of the data (Mitchell, 2011). Technology investment has proven to be most effective in making organizational change, most especially when it comes to operational efficiencies (Tucci, 1996).

Logistic carriers by type/mode (rail, water, air, \&highway) have invested in response to retailers' demands. However the level of technology integration has varied by value chain position and needs/utility within the industry. In comparison, retailers havealso invested heavily in Radio Frequency Identification (RFID) technology since 2002.In 2003, Wal-Mart announced that it would implement RFID technology in its supply chain. In 2006, it announced that a RFID pilot study resulted in 30\% reduction in the out-of-stock ratio (Hargrave, Waller, \& Miller, 2006). Wal-Mart completed the introduction phase of the RFID project by the end of 2007 and in 2008 it imposed its SAMSCLUB suppliers "RFID compliance penalty" for each pallet received without an RFID tag (Shin \& Tucci, 2015). This second phase, implementation, allowed it to quickly move towards a fully integrated IT/Kanban supplier/buyer inventory system. It is clearly recognized by many that the logistic suppliers efficiencies directly impact the overall financial performance of the firm (Shin \& Eksioglu, 2015; Meixell \& Norbis, 2008). In an effort to obtain sustainability, logistics cannot be underestimated. Logistics can account for $1 / 5^{\text {th }}$ of total production costs and a majority of logistical costs are in actuality transportation costs of goods and/or supplies (Russell and Taylor, 2003). In addition, according to the 2011 State of Logistics Report by the Council of Supply Chain Management and Professionals, the percentage of domestic U.S. GDP is $8.3 \%$ for the logistics industry.

\subsection{Early Adoption}

Historically, the U.S. transportation system has been heavily dependent on trucking for the last 50 years. According to the 2010 report of the American Trucking Association, the truck mode accounts for $80 \%$ of domestic volume. Most interesting is that railroads as a logistics supplier began their RFID investment in 1994, a full decade before the Wal-Mart mandate (Cleveland, 1995). However the initial investment was not done to establish a clear path towards sustainability, but towards a means of revenue allocation for shared loads across different railroads, all of whom touched the load along its path to destination (Welty, 1993). Nevertheless, the lead time in implementing RFID may have been key to the real benefit of strategy, implementation, and technological fit (Hunt et al., 2007). RFID enables firms to track merchandise wirelessly (Kerr, 2007). RFID allows for tracking of goods in a systematized way and can work seamlessly with computerized inventory management systems (Shin and Eksioglu 2014). These combined systems emerged as an integrated e-Kanban system that allows the retailer to accurately track product location from manufacturer, to distributor, to storage pallets, to distribution center, to carrier (by type), and finally to the store. With an integrated and dynamic system, the possibility to transition from the old fashioned card system to a dynamic e-Card system allows managers to make on-the-fly stockingand inventory decisions resulting in reduced inventory and increased productivity.

One good example of technology investment within the rail system is the ability for customers to track their rail shipment and "encourage" shippers to reduce siding time. Early on, this one feature has increased the visibility of inefficiencies as well as accountability for just-in-time inventory systems (Kerr, 2007). As accountability increased, the result is improved performance in what was once a lagging industry due to poor on-time delivery cycles. However, as performance has improved, so did the logistics mix in selecting the how as well as who would deliver the inputs into the retail chain (Meixell \& Norbis, 2008). In fact, many businesses, who once would not ship by rail due to inefficiencies, now consider rail as an essential component in their logistics mix due to intermodal RFID enhancements (Dutton, 2013). As seen by industry reporting and the intensity of investment, Rail has benefitted from RFID investment.From anecdotal observations the authors hypothesize, that companies that have better technology fit, will enjoy greater benefits from investment in technology, specifically RFID. As a definition "better fit" is being defined as those modes of logistics better conforming to the limitations of RFID technology as found in the literature.

\subsection{Technology Limitations}

In support of the previously discussed technology fit limitation, other companies have been hesitant to adopt RFID technology because of uncertainty of Return on Investment (ROI) (Shin, Tucci, \& Odom, 2014). RFID technology has many benefits: increase in inventory accuracy, reduced inventory cost, decrease in lost items, reducing out-of-stock time span, and improvement of in-store customer support. Of primary concern to many of the companies is overcoming the technological complexity of integrating each of these systems and the required technical support to maintain these systems. Looking at an outside supplier for either turn-key implementation, or integration has proven successful through fourth party logistic suppliers (Hingley, Lindgreen, Grant, \& Kane, 2011). 


\subsection{Importance of Fit}

One of the reasons that the railroads have had massive growth, is their use of RFID since the early 1990's. Empty and full rail cars sitting for weeks on sidings is quickly becoming history. Railroads have been using RFID to track all rail shipments for revenue allocation, security, reduce delivery times, and to minimize time cars sit on sidetrack waiting in que (Zhang, 2013; Yahia, 2011) Rail cars with loads moving and being delivered generate profit and with reverse logistics playing a stronger role, empty cars are efficiently returned to points of origination as quickly as possible (Turrisi et al., 2013). However it was not until about 2000 that they learned to use RFID effectively as a tool to enable a sustainability strategy. Improvements in B2B communications, computing power and open database $\left(3^{\text {rd }}\right.$ party access) put pressure on Rail logistic suppliers to have more timely and realistic delivery schedules. As delivery times continue to improve, it has allowed rail to quickly become the preferred method of shipping since on-time delivery has increased significantly. In fact, many frozen food companies now seek out rail as a preferred provider (Dutton, 2013). Energy expenditures to ship by rail for most goods is lowest, second only to goods shipped over water when available.

\subsection{Competitive Advantages Leading to Sustainability}

A lean logistics strategy accomplished through intensive investment in technology as a method of improving competitiveness and reducing costs has proven to be very effective. Logistics companies started investment in RFID in the early 1990's and have long capitalized on this concept since the advent of RFID that allowed the creation of real-time databases (Cleveland, 1995; Atkinson, 2000). By doing so, it created the opportunity to integrate efficient economic shipping strategies in order to target quantity/quality loading manifests. Minimizing inventory (idled in-transit goods) has proven to be a means to developing a sustained competitive advantage for shipping companies through cost reduction. Perhaps a bigger driver for the railroads was the advent of the internet, B2B shared databases, and the ability for customers to "see" and track their load in transit allowing them to better plan production and operations (Kaufman, 2000).

The question remains: does this impetus have immediate (short term) or finite benefits, or does the implementation have synergistic spinoffs that benefit the company? Of the four logistic types, who benefits the most and why? For a shipper, cost containment through effective loading of the transportation system, and inventory managementhas the ability to reduce the storage footprint (through maximizing the utilization of a dynamic e-Card system). As further impetus, the government influences this change in behavior throughinventory taxes and insurance costs which are the driving factors propelling corporations seeking efficiency and profitability (Taiichi, 1988; Selden 1997; Emiliani, et al., 2007; Horngren, 2011). However, one of the great difficulties in capturing the cost advantage is "inter-industry" cooperation and global reach with each company's infrastructure (Glaser-Segura, Tucci, \& Anghel, 2006). A direct benefit of reduced inventory also makes the entire logistic chain "greener" by minimizing spoilage, shrinkage, and obsolescence through inventory reduction or elimination altogether (idled or in transit stored inventory). The ability to maintain your shipment stream and minimize delayed shipments (goods on-dock, siding, or idled in-yard) allows logistic companies the ability to accomplish two goals simultaneously; increased profitability and go "Green."Anderson (2010) describes the advantages of technology solutions for non-manufacturing sectors and the multiple potential peripheral benefits of full integration to reduce costs. The benefits of making "in-transit" decisions for shipments and changing delivery orders on the fly (e-Carding) provide flexibility heretofore unheard of.

According to Chandran (2003), much of the efficiencies in the logistical supply chain propelled many companies forward in profitability, especiallythose who have invested most in technology and efficient supply chain practices. Many improvements in these systems are made possible by automated distribution centers and computerized inventory systems (Chen, 2011). These integrated systems Ocean ship, to rail, to truck benefit from efficient supply chain management systemsdue to reduction in lead time, faster inventory turn-over,accurate forecasting of inventory level, and better working capital utilization (Chandran, 2003). In contrast, many companies do not see the fit with RFID technology with their current operations either due to sunk costs in current technologies or poor fit with systems turn-around time requirements (Bajkowski, 2005; Hoffman, 2004). This has been true historically for both Fed Ex and UPS, both leaders in overnight logistics.

\section{Method}

A financial analysis of the logistic industry as broken down into its four primary categories is analyzed by evaluating productivity over time. These four categories of carriers are: rail, water, air, and highway. The financial data of these U.S. competitors in the logistics industry is performed by the authors to answer the following three questions: (1) is there a significant difference in productivity by transportation type? (2) is there a change in productivity by transportation type after investment in technology (RFID) compared to their competitors between 
2001 and 2013? and (3) which factor can influence change in the productivity ratios for each of the four logistical modes?

\subsection{Participants' Characteristics}

A total of 98 companies were examined in this study. These companies are classified in the four key modes of transportation logistics: 1). Water Mode (Ocean Shipping), 2). Rail, 3). Highway (Trucking), and 4). Air freight.The first criterion for inclusion in this research was that the companies used must be publicly traded in order to gain available financial data. Once the companies were selected, the next step was to identify how to measureproductivity and logistics management efficiency for each firm. It was determined the most objective way to do this was through observation of each company's financial statements. Each of these companies were initially identified through Yahoo Finance (http://finance.yahoo.com). Each of these four industry sectors are public companies listed in NYSE and NASDAQ. Each of the four logistic industries has multiple competitors: Railroads (15), Trucking (20), Air Delivery and Freight Services (16), and Shipping (47). The number in the parenthesis is the number of companies in each industry. The total number of companies in these four industries is 98 .

\subsection{Sampling Procedures}

The data from 2000 through 2013 was downloaded from CompuStat Database with the above 98 companies' ticker symbols. When the data were analyzed, there were several companies for whom there was incomplete data. Out of 98 companies, excluding incomplete data records we also excluded companies with less than 100 employees. This resulted in a data set of fifty-six companies that were selected for analysis. The following table shows the number of data records used in each year in each industry.

Table 1 . Number of companies by mode

\begin{tabular}{llllllllllllllll}
\hline & 2000 & 2001 & 2002 & 2003 & 2004 & 2005 & 2006 & 2007 & 2008 & 2009 & 2010 & 2011 & 2012 & 2013 & Total \\
\hline Rail & 12 & 12 & 12 & 12 & 12 & 13 & 14 & 14 & 14 & 13 & 13 & 14 & 14 & 14 & 183 \\
Truck & 14 & 14 & 16 & 16 & 16 & 16 & 16 & 16 & 17 & 17 & 18 & 18 & 18 & 18 & 230 \\
Air & 8 & 8 & 9 & 10 & 10 & 10 & 10 & 10 & 10 & 11 & 11 & 11 & 11 & 11 & 140 \\
Ship & 4 & 4 & 6 & 6 & 6 & 7 & 10 & 11 & 12 & 11 & 12 & 12 & 12 & 13 & 126 \\
\hline
\end{tabular}

Gross Income (GI), which is sales less the cost of goods sold, is a commonly used output measurement. To compare the productivity of the above four industries, Gross Income Per Employee (GIPE), which is Gross Income (GI) divided by the number of full-time employees (FT), is used in the following table. Compared to the other three industries, the Ocean Shipping industry has a large standard deviation.

Table 2. Gross income per employee

\begin{tabular}{clllllllllllllllll}
\hline & 2000 & 2001 & 2002 & 2003 & 2004 & 2005 & 2006 & 2007 & 2008 & 2009 & 2010 & 2011 & 2012 & 2013 & Mean & S.D. \\
\hline Rail & 47,734 & 46,147 & 48,371 & 50,399 & 49,015 & 63,623 & 81,405 & 85,864 & 82,821 & 84,684 & 81,566 & 88,011 & 98,205 & 106,247 & 72,435 & 20,836 \\
Truck & 34,081 & 33,097 & 44,531 & 48,668 & 52,400 & 64,859 & 62,330 & 60,316 & 61,776 & 51,970 & 58,989 & 66,603 & 57,844 & 60,705 & 54,155 & 10,703 \\
Air & 46,434 & 49,331 & 48,778 & 51,478 & 56,982 & 65,411 & 66,868 & 70,239 & 76,250 & 73,736 & 83,001 & 87,749 & 79,750 & 78,042 & 66,718 & 13,929 \\
Ship & 268,827 & 272,549 & 193,360 & 230,836 & 151,564 & 170,327 & 169,554 & 153,798 & 383,613 & 208,810 & 206,186 & 211,451 & 136,820 & 203,123 & 211,487 & 64,090 \\
\hline
\end{tabular}

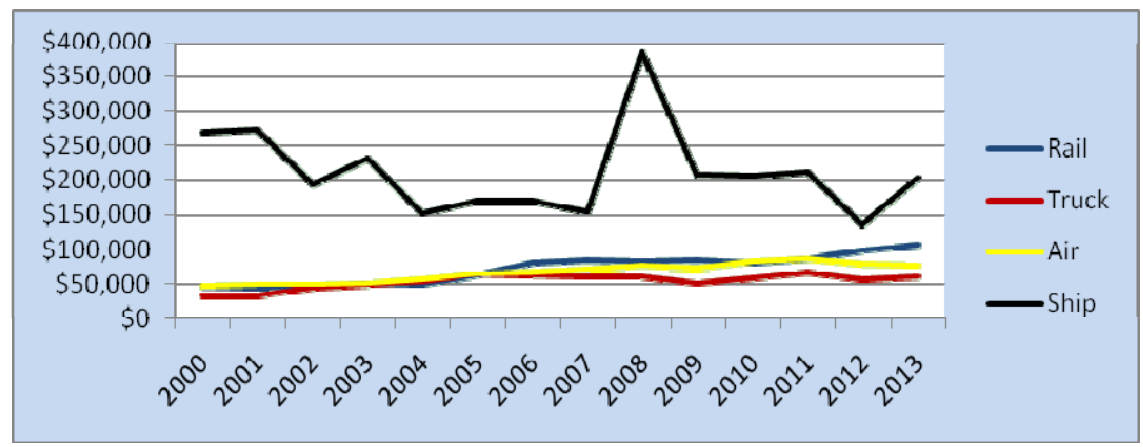

Figure 1. Gross income by mode 
ARIMA (Arithmetic Moving Average) was used to smooth the data from 2002 through 2011. Particularly onerous in the analysis of the data was Ocean Shipping during the 2008 fiscal year. That year alone, shipping jumped from $150 \mathrm{~mm}$ in 2007 to $383 \mathrm{~mm}$ in 2008 and back down to $208 \mathrm{~mm}$ in 2009 (Table 2). The authors could find no reason for this anomaly.

Table 3. ARIMA adjusted income by mode

\begin{tabular}{|c|c|c|c|c|c|c|c|c|c|c|}
\hline & 2002 & 2003 & 2004 & 2005 & 2006 & 2007 & 2008 & 2009 & 2010 & 2011 \\
\hline Rail & 48,323 & 50,668 & 56,981 & 65,544 & 74,203 & 81,061 & 83,714 & 84,002 & 86,194 & 90,812 \\
\hline Truck & 42,384 & 48,644 & 54,839 & 58,520 & 61,148 & 60,709 & 58,680 & 59,049 & 59,343 & 59,944 \\
\hline Ship & 226,735 & 199,300 & 183,546 & 170,941 & 190,317 & 224,133 & 233,523 & 245,309 & 221,666 & 190,106 \\
\hline
\end{tabular}

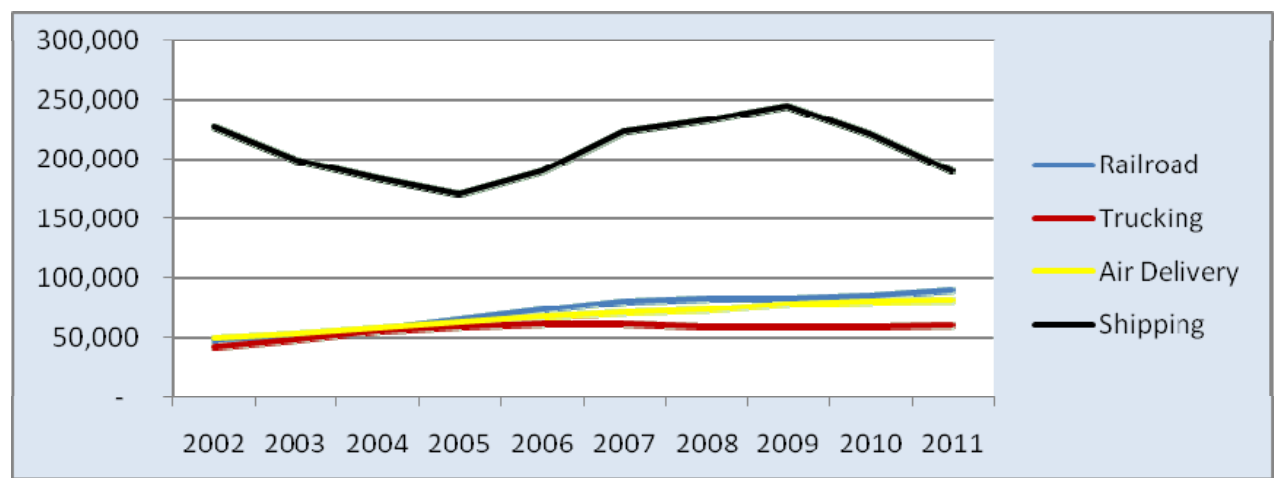

Figure 2. ARIMA adjusted income by mode

In the above graph of moving average of GIPE, railroad, trucking, and air delivery have the similar pattern and their labor productivity has been increasing since 2002. Shipping industry's labor productivity has been much higher than those of the other three industries but the fluctuation of the GIPE is severe. Ocean Shipping has been very sensitive to the world's economicfluctuations/situation and there are two times when there was a dramatic decrease inproductivity in its logistic segment that occurred both in 2002-2004 and 2009-2011 time periods. Anecdotal news reports also illustrated the increased awareness of piracy during these periods when significant ransoms were paid to keep freight moving on the high seas.

\section{Analysis and Results}

Return on Assets (ROA) and Cash Conversion Cycle (CCC) are popular metrics to investigate financial performance and financial efficiency of supply chain and logistics. ROA shows a ratio of net income out of total assets and CCC shows length of days to convert from inputs like raw materials and parts into cash flows. CCC is composed of three parts: days in sales outstanding (DSO), days in inventory outstanding (DIO), and days in payable outstanding (DPO). CCC is used to compare the companies in the same industry to evaluate the efficiency of cash management. Because the transportation industry helps to move inventory of other companies, many of companies in air transportation and shipping industry do not have inventory, which displays zero in their financial statement. The CCC in this analysis is calculated without days in inventory outstanding: CCC $=$ DSO - DPO. The following table presents mean values of ROA and CCC during the 14 years (2000-2013). Air logistics has the highest ROA, which means that it is the most profitable using its vehicle (airplane) to generate revenue. Railroad has the lowest CCC, which means that Railroad industry is very efficient to management of cash flowing.

Contrary to publicly stated beliefs about inventory, when a rail carrier places a rail car/box car on a siding and lets it sit for several weeks, they do not claim it as inventory, but in reality, that is what it becomes. Historically, and as an example of what is now considered both unlawful and unethical (tax avoidance), in the 1970's, car manufacturers shipped cars to dealerships, (when dealers often lacked inventory space) the manufacturer would have them shipped to an intermediate "holding" yard and claimed "good in transit". It was a dishonest way of circumventing inventory tax liabilities. 
Table 4. Mean values of ROA and CCC in four transportation modes

\begin{tabular}{lcccc}
\hline & Rail & Truck & Air & Ship \\
\hline ROA & 0.040 & 0.043 & 0.070 & 0.034 \\
CCC & -16.74 & 28.68 & 14.79 & 13.15 \\
\hline
\end{tabular}

The following graphs shows trends of moving average of CCC (figure 3) and ROA (figure 4) of four transportation industries since 2002. We believe because the logistics industry dependsheavily on the economy, the global financial crisis of 2007-2008 was the main cause of this shape of ROA pattern in the associated graph. The railroad industry has shown a much lower CCC since 2000 than the other three industries. In essence, railroad logistic suppliers are more efficient in cash management among the four logistics industries.

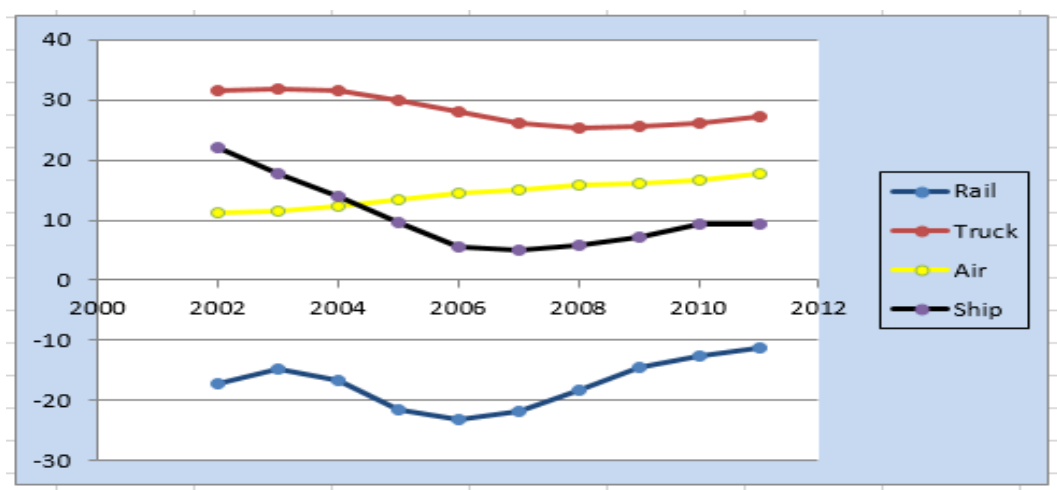

Figure 3. Moving average of CCC of four transportation modes

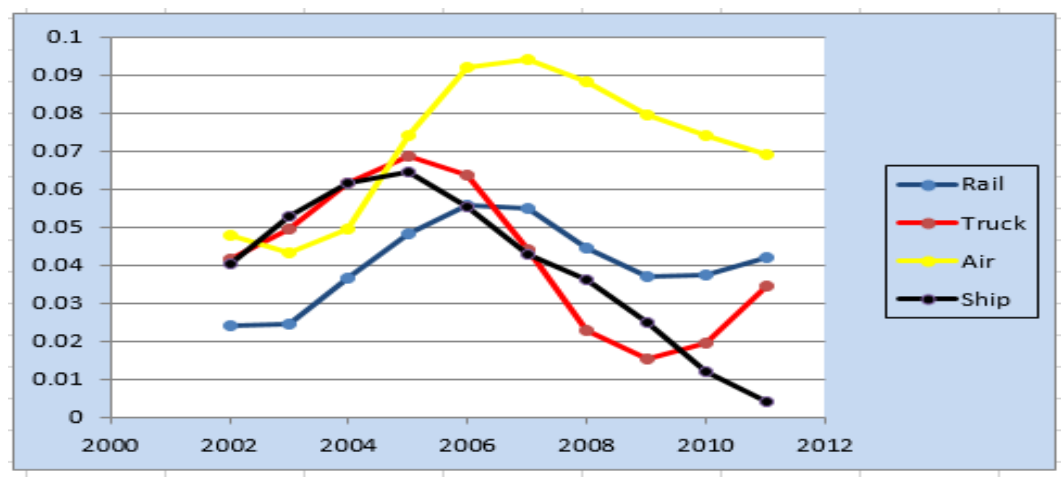

Figure 4. Moving average of ROA of four transportation modes

\subsection{Statistics and Data Analysis}

In the regression analysis, two financial ratios (CCC \& ROA) influence the productivity ratio of GIPE.The data set used in this analysis is panel data, which consists of cross sectional data and time series. The dependent variable is GIPE and the independent variables are CCC and ROA. The following equation is the regression model which is applied to four transportation industries.

$$
G I-E M P_{i j}=\beta 0+\beta 1 * C C C_{i j}+\beta 2 * R O A_{i j}+\varepsilon_{i j}
$$

Where $\mathrm{i}=2000 \sim 2013, \mathrm{j}=1 \sim 14$ (rail), 1 18(truck), 1 11(air), 1 13(ship)

\subsection{Regression Analysis}

Estimating the panel data regression model by OLS could give a biased solution. To test whether the regression model meets OLS requirements, the following three tests are conducted: BP-Test, DW-Test, and VIF (Variance Inflation Factor). The BP-Test is for homoscedasticity assumption and the DW-Test is for autocorrelation problem. VIF is calculated for multi-collinearity. Table 5 presents results of the above three tests. The model of Ship mode does not have any problem in the above three tests. However, the rest of three modes cannot use the OLS model. 
Panel data regression model was developed to overcome the problems proved by BP-Test and DW-Test. There are two approaches in the panel data regression models, fixed effect and random effect. PH-Test can check which approach is more appropriate. In conclusion, Rail and Air mode use random effect regression model and Truck mode uses fixed effect regression model while Ship mode uses OLS.

Table 5. Results from OLS model assumption tests

\begin{tabular}{|c|c|c|c|c|c|c|}
\hline & $\begin{array}{l}\text { BP-Test } \\
\text { (p-value) }\end{array}$ & $\begin{array}{c}\text { DW-Test } \\
\text { (d, p-value) }\end{array}$ & VIF & OLS Model & $\begin{array}{l}\text { PH-Test } \\
\text { (p-value) }\end{array}$ & $\begin{array}{c}\text { Fixed / } \\
\text { Random }\end{array}$ \\
\hline Rail & $\mathrm{p}=1.2 \mathrm{e}-06^{*}$ & $\begin{array}{c}\mathrm{d}=1.3553 \\
\mathrm{p}=4.9 \mathrm{e}-06^{*}\end{array}$ & vif $=1.001$ & Not Accepted & $\mathrm{p}=0.2506$ & Random \\
\hline Truck & $\mathrm{p}=0.061$ & $\begin{array}{c}\mathrm{d}=0.6725 \\
\mathrm{p}=2.2 \mathrm{e}-16^{*}\end{array}$ & vif $=1.020$ & Not Accepted & $\mathrm{p}=0.0137^{*}$ & Fixed \\
\hline Air & $\mathrm{p}=0.026^{*}$ & $\begin{array}{c}\mathrm{d}=1.2612 \\
\mathrm{p}=4.2 \mathrm{e}-06^{*}\end{array}$ & vif $=1.041$ & $\begin{array}{c}\text { Not } \\
\text { Accepted }\end{array}$ & $\mathrm{p}=0.6823$ & Random \\
\hline Ship & $\mathrm{p}=0.4070$ & $\begin{array}{c}\mathrm{d}=1.8306^{* *} \\
\mathrm{p}=0.1672\end{array}$ & vif $=1.002$ & Accepted & NA & NA \\
\hline
\end{tabular}

* reject with $\alpha=0.05$

$* * \mathrm{~d}(3,126)_{L}=1.62233, \mathrm{~d}(3,126)_{\mathrm{H}}=1.68639$

Table 6 presents result of regression models in the four transportation industries. The $\beta 1$ is a coefficient of CCC and the $\beta 2$ is a coefficient of ROA. According to p-values of coefficients, no industry has acceptable p-value in both coefficients: While in the rail and air industries, ROA has a positive influence to GIPE, in the ship industry, $\mathrm{CCC}$ has a positive influence to GIPE. However, in the truck industry, both coefficients are not acceptable and the regression model itself is not acceptable with a 5\% significance level. Except for Rail industry, the R-square value is relatively low.

Table 6. Results of regression model of four transportation industries

\begin{tabular}{|c|c|c|c|c|c|}
\hline & Model & $\begin{array}{c}\beta 1 \\
\text { (p-value) }\end{array}$ & $\begin{array}{c}\beta 2 \\
\text { (p-value) }\end{array}$ & $\begin{array}{c}\text { F-Stat } \\
\text { (p-value) }\end{array}$ & R-Square \\
\hline Rail & Random & $\begin{array}{c}69.22 \\
(0.3731)^{*}\end{array}$ & $\begin{array}{c}364,043.09 \\
(0.000)\end{array}$ & $\begin{array}{c}22.73 \\
(0.000)\end{array}$ & 0.200 \\
\hline Truck & Fixed & $\begin{array}{c}-279.31 \\
(0.3596)^{*}\end{array}$ & $\begin{array}{l}43,694.94 \\
(0.1386)^{*}\end{array}$ & $\begin{array}{c}1.5022 \\
(0.225)^{*}\end{array}$ & 0.014 \\
\hline Air & Random & $\begin{array}{c}211.85 \\
(0.378)^{*}\end{array}$ & $\begin{array}{c}46,188.03 \\
(0.011)\end{array}$ & $\begin{array}{c}4.1545 \\
(0.0177)\end{array}$ & 0.056 \\
\hline Ship & OLS & $\begin{array}{l}-1,664.6 \\
(0.0153)\end{array}$ & $\begin{array}{c}94,845.9 \\
(0.7107)^{*}\end{array}$ & $\begin{array}{l}3.061 \\
(0.05)\end{array}$ & 0.047 \\
\hline
\end{tabular}

* reject with $\alpha=0.05$

\section{Discussion}

The intensity in investment of RFID and associated database systems to create "real-time" inventory systems has enabledthree of the four shippers to benefit over time resulting in increased productivity and profitability. Increasing productivity, while admirable also creates an overall more efficient market, and simultaneously contributes toward the creationof a more "green" environment by the reduction of idle inventory, delivery error, leading to the reduction in the number of times shipments must be handled. More importantly, the reduction of idle inventory reduces waste through spoilage, shrinkage, and reduces carded inventory. The increase of speed of goods simultaneously increases the Cash Conversion Cycle (CCC) frequency which is a contributor towards financial health. As this technology is enhancing "in-transit" inventory management, more utilitarian techniques will emerge to further fine-tune logistical decisions. The combined synergy of significantly advanced information technology, speed of computing, reverse logistics, and speed of data transmission in the B2B world should not be underestimated as a sustainable strategy. This article clearly illustrates that technical expertise and information systems assets ability to overcome historical time and distance issues should also not be underestimated. It is evident that the logistics industry benefits greatly from RFID investment (Hsieh et al., 2010). 
It is evident that the rail industry is clearly the acknowledged leader andearly pioneer in systemizing their "green" sustainability approach in minimizing inventory (side-tracked cars) while at the same time increasing their CCC as the data suggests (Attaran, 2006, 2011). RFID technology as the backbone of a real-time scheduling solution in the rail industry indicates great support for improvements in financial ratios for inventory and profitability over competitors after the technology was mastered.

In our Productivity and CCC analysis, we found that there is a strong relationship between reported investment in technology and profitability in the logistics industry when RFID is fully integrated. Because of this strong relationship, we should be able to see the benefits of the RFID technology on profitability in the future in other companies as they approach the mature phase of the learning curve in full integration of RFID and real-time inventory systems. Considering that Railroads invested heavily in RFID in the mid 1990's, evidence is ample that sustainability improvements are a long-term investment often not seen for a decade or more, but are necessary for the sustainability necessary for future generationsuccess.

\section{References}

Attaran, M. (2006). The Coming Age of RFID Revolution. Journal of International Technology and Information Management, 15(4).

Attaran, M. (2011). The Supply and Demand for RFID. Industrial Engineer, 43(12), 26-31.

Bajkowski, J. (2005). RFID doesn't deliver what FedEx needs. Computerworld, 39(14), 14.

Bearth, D. P. (2012). Advanced RFID tracks more than location. Transport Topics, (3992), A6-A7.

Chandran, M. H. (2003). Wal-Mart's Supply Chain Management practices. Retrieved from http://mohanchandran.files.wordpress.com/2008/01/wal-mart.pdf

Chen, I. (2011). The dynamic effects of collaborative transportation management and RFID implementation in the railroad supply chain. North Dakota State University.

Chertow, M. R. (2000). The IPAT Equation and Its Variants. Journal of Industrial Ecology, 4(4), 13-29. http://dx.doi.org/10.1162/10881980052541927

Dutton, G. (2013). Intermodal is viable - and growing - for cold shipping. World Trade, 26(1), 41-43.

Ehrlich, P. R., \& Holdren, J. P. (1971). Impact of Population Growth. Science, 171(3977), 1212-1217. http://dx.doi.org/10.1126/science.171.3977.1212

Emiliani, B., Stec, D., Grasso, L., \& Stodder, J. (2007). Better thinking, better results: case study and analysis of an enterprise-wide lean transformation (2nd ed.). Kensington, Conn: Center for Lean Business Management.

Freeman, R. B., Nakamura, A. O, Nakamura, L. I., Prud'homme, M., \& Pyman, A. (2011). Wal-Mart Innovation and Productivity: A Viewpoint. Canadian Journal of Economics, 44(2), 486-508. http://dx.doi.org/10.1111/j.1540-5982.2011.01641.x

Glaser-Segura, D. A., Tucci, J. E., \& Dan Anghel, L. (2006). Supply Chain Management and the Romanian Transition. Amfiteatru Economic, 8(19).

Hingley, M., Lindgreen, A., Grant, D. B., \& Kane, C. (2011). Using fourth-party logistics management to improve horizontal collaboration among grocery retailers. Supply Chain Management, 16(5), 316-327. http://dx.doi.org/10.1108/13598541111155839

Horngren, C. T. et al. (2011). Cost Accounting: A Managerial Emphasis. Pearson Publishing.

Hunt, D., Puglia, A., \& Puglia, M. (2007). RFID - A Guide to Radio Frequency Identification. Hoboken, New Jersey: John Wiley \& Sons, Inc. http://dx.doi.org/10.1002/0470112255

Kaufman, L. H. (2000). What Intermodal Needs Next. Railway Age, 201(4), 47-52.

Kerr, J. (2007). Dow makes RFID work. Logistics Management, 46(10), 49-53.

Meixell, M. J., \&Norbis, M. (2008). A review of the transportation mode choice and carrier selection literature. $\begin{array}{llll}\text { International Journal of Logistics } & \text { Management, } & 19(2), & \text { 183-211. }\end{array}$ http://dx.doi.org/10.1108/09574090810895951

Mitchell, S. (2012). Walmart's Greenwash. Institute for Local Self Reliance, Internal Report.

Ohno, T. (1988). Toyota Production System: Beyond Large-Scale Production (English translation ed.). Portland, Oregon: Productivity Press.

O'Neill, B. C., MacKellar, F. L., \& Lutz, W. (2004). Population, greenhouse gas emissions, and climate change. In 
W. Lutz, W. C. Sanderson, \& S. Scherbov (Eds.), The End of World Population Growth in the 21st Century: New Challenges for Human Capital Formation \& Sustainable Development (pp. 283-314). London: Earthscan Press.

Russell, R., \& Taylor, B. (2003). Operations Management. Upper Saddle River, NJ: Prentice-Hall.

Selden, P. H. (1997). Sales Process Engineering: A Personal Workshop. Milwaukee, WI: ASQ Quality Press.

Shin, S., \& Tucci, J. (2015). Wal-Mart's Dilemma in the 21 st Century: Sales Growth vs. Inventory Growth. Journal of Applied Business Research, 31(1), 37-45.

Shin, S., \& Eksioglu, B. (2015). An Empirical Study of RFID Productivity in the U.S. Retail Supply Chain. International Journal of Production Economics, 165, 89-96.

Shin, S., \& Eksioglu, B. (2014). Effects of RFID Technology on Efficiency and Profitability in Retail Supply Chains. Journal of Applied Business Research, 30(3), 633-645.

Shin, S., Tucci, J., \& Odom, D., (2014). Wal-Mart's Leadership in Retail Supply Chain. Journal of Management Systems, 24(3), 21-30.

Smart Label Solutions. (2007). White Paper: What is the ROI of RFID? Retrieved from http://www.slsrfid.com/pdf/WhitePaper-RFID-ROI.pdf

Tucci, J. E. (1996). The Influence of Change in Organizational Size, Level of Integration, and Investment in Technology on Task Specialization. Dissertation, University of North Texas.

Turrisi, M., Bruccoleri, M., \& Cannella, S. (2013). Impact of reverse logistics on supply chain performance. International Journal of Physical Distribution \& Logistics Management, 43(7), 564-585. http://dx.doi.org/10.1108/IJPDLM-04-2012-0132

Welty, G. (1993). Rebuilding America's Railroads: The Information Evolution. Railway Age, 194(2), 85.

Yahia, Z. M. (2011). RFID and its benefits: A multiple case analysis. Assembly Automation, 31(3), $251-262$. http://dx.doi.org/10.1108/01445151111150596

Zhang, R. (2013). A transportation security system applying RFID and GPS. Journal of Industrial Engineering and Management, 6(1), 163. http://dx.doi.org/10.3926/jiem.668

Commoner, B. (May 1972). A Bulletin Dialogue: on "The Closing Circle-Response". Bulletin of the Atomic Scientists, 17-56.

Cleveland, V. (Feb. 1995). Amtech corp. announces fourth quarter and 1994 operating results. Business Wire.

Atkinson, H. (Jan. 2000). China railways to adopt advanced ID technology. Journal of Commerce.

Anderson, D. (April 2010). Kanban. Blue Hole Press.

Hoffman, W. (2004). No RFID rush at UPS. Traffic World, 1-11.

\section{Copyrights}

Copyright for this article is retained by the author(s), with first publication rights granted to the journal.

This is an open-access article distributed under the terms and conditions of the Creative Commons Attribution license (http://creativecommons.org/licenses/by/3.0/). 